\title{
Psychological Peculiarities of Professional Burnout of Teachers of High Medical Educational Institutions
}

\author{
Nadiia Pobigun*, Uliana Shalamai
}

\begin{abstract}
In the article the relevance of the outlined problem in the context of the entrance of Ukraine in the world medical educational space is covered. The essence of the professional burnout of teachers of the higher medical educational institutions (HMEI), which is characterized by the gradual loss of life tone by the subject under influence of prolonged stress in the professional teaching activity and is manifested by symptoms of chronic fatigue, general exhaustion, depersonalization, reduction of professional achievements, etc., is determined too. The objective of the study - to substantiate reasons, peculiarities, objective and subjective factors of the professional (emotional) burnout of teachers of the HMEI.

In the investigation the historical-systematic, comparative method and objective-specific method are used.

It is emphasized that the syndrome of professional burnout can lead to general decrease of the effectiveness of the professional activity of the teacher, deformation of interpersonal relationships as well as decrease of activity in the creative professional self-improvement, self-development. The threats and risks of the professional burnout of the teachers of medical university in providing the quality of professional training of future healthcare professionals, are characterized.
\end{abstract}

\section{Keywords}

the world medical educational space; professional burnout; higher medical educational institutions; professional activity of teacher; quality of professional training.

Ivano-Frankivsk National Medical University, Ivano-Frankivsk, Ukraine

*Corresponding author: nadiia.pobigun@ukr.net

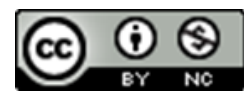

Copyright (C)Nadiia Pobigun, Uliana Shalamai, 2019

\section{Problem statement and analysis of the latest research}

Increase of the professional competence of healthcare professionals worldwide is identified as a major factor in health care reform. Along with the general requirements for a health professional who could meet the necessities of both the individual person and of the community as a whole, there are growing requirements for medical educational institutions for continuous improvement of professional development. At the same time, the level of state support of these institutions should be related to the quality of training of specialists and their social importance. In the last decade, this prob- lem has been given considerable attention by the scientific researchers and practitioners of medical education in the world. Numerous WHO scientific sources, publications by the World Federation of Medical Education (WFME) staff, the works of C. Boelen $(1998,2001)$ can be considered the basic ones, research by experts of the European Association of Medical Education (EHMA), indicate the necessity to approximate the medical education national standards to international ones [3]. Entrance to the global medical educational space requires a significant improvement in the quality of professional training of health care professionals in Ukraine, the introduction of innovative approaches, 
in particular, modern computer technologies and best European practices [11] into the educational process of institutions of higher medical education.

Today in Ukraine, the first among the countries of Eastern Europe and the CIS, a system of quality management of higher medical education and certification of medical personnel training is developed and implemented into practice. The introduction of modern pedagogical, psychological and therapeutic innovations in the process of training medical workers, approximation of contents, forms of organization of educational process, requirements and quality of practical training of medical personnel to international standards have contributed to a significant increase in the number of medical students and citizens of foreign states in our country [8].

New societal challenges are increasingly demanding for the professional competence of teachers in this field, and therefore changes in different spheres of life require flexibility and mobility in professional activity, openness and willingness to introduce medical innovations in the educational process of a medical university. Such conditions create high stressful environment and often lead to severe psycho-emotional overload, because teachers work in the conditions of socio-economic instability, insufficient material support, increased intensity of professional-communicative activity, systematic load on the vocal and acoustic apparatus, hypodynamia etc. Therefore, a high school teacher is in a risk zone of occupational stress, the result of which is called "professional burnout" syndrome.

In the contemporary scientific literature, the outlined problem is reflected in the following aspects: the phenomenology of professional burnout, methods of its psychodiagnosis, psychoprophylaxis, psychocorrection. At the same time, the psychological peculiarities of its development in the professorteaching staff of the institutions of higher medical education (HMEI) have not been adequately highlighted in scientific research. Therefore, the question of prevention and diagnostics of the professional burnout of medical university teachers is particularly relevant in the environment of modern educational and medical challenges.

The objective of the study - is to substantiate the psychological peculiarities of the professional burnout of teachers of IHME and to identify the main factors for its prevention.

\section{Research Methods}

The historical-systemic and comparative methods made it possible to investigate the peculiarities of the development of the concept of "professional burnout" on the basis of foreign and native experience. Application of this method allows us to systematize scientific researches of scientists on the outlined problem, to distinguish common and different aspects in their studies, as well as to make certain prognostic conclusions about theoretical and practical aspects of realization of outlined definition in modern conditions of reforming the health care system, its integration into the world medical educational space.

Objective-purposeful method was used for analysis and synthesis of the contents of psychological, pedagogical, medical literature on the problem of professional burnout of the HMEI teacher, as well as justification of the expediency of introduction of medical innovations in the educational process and at the same time, the prevention of professional burnout in order to improve the quality of future doctors' training.

\section{Representation of the Main Research Material}

The problem of professional burnout of professions of the type "person-to-person" has been covered in numerous scientific researches in the human sciences.

In the post-Soviet space, the phenomenology of burnout was investigated by B.H. Ananiev in the 1960s, using the notion of "emotional burnout" in the interpersonal professional interaction [2].

For the first time, the scientific concept of stuff burnout was offered by the American psychiatrist G. J. Freudenberger in 1974. Actually, this theory became the basis for the formation of a clinical approach in the works of a scientist, who does not accidentally interpret the essence of burnout in pro- 


\section{Psychological Peculiarities of Professional Burnout of Teachers of High Medical Educational}

Institutions - 3/7

fessional activity as a certain mental disorder related to the individual characteristics of the person [12].

In the social psychology of the 1970s, the first valid methods of psycho-diagnosis of occupational burnout, introduced by C. Maslach, have emerged. For the first time, a researcher described this term as a "burnout" - as a result of the problems of mental disorders of the subject of professional activity, his/her emotional, mental and physical exhaustion (this concept is widely used today) [14].

As we can see, in the 1970s there were special conditions for individual-professional personal development, successful career development, respectively the requirements as for the professional skills and quality of service delivery in various spheres of life activity increased. Therefore, the workload on specialists increased, that gradually led to their gradual exhaustion, professional burnout and became the subject of scientific research. Actually, these phenomena are observed in modern society when we have unstable socio-economic, political and other conditions, which are a consequence of prolonged existential stress. The studied concept is often interpreted also as: "emotional weakness", "psychological exhaustion", "burnout", "burnout of emotions" and others.

Hungarian psychiatrist and neuropathologist I. Hardy (1988) for a reason uses the term "poisoning by humans" when referring, for example, to the field of medical or educational services. This situation arises due to the work of medical professionals with a large number of patients, which leads to the loss of enjoyment from professional work, psychological and somatic exhaustion, emotional instability, nervousness, indifference, etc. [9].

The effectiveness of a teacher's professional activity depends on his motivation, his interest in the results. Accordingly, the opposite phenomenon, as was noted by Ph. Rothlin and P. R. Werder, is the boredom due to this activity. Scientists use the concept of "boreout" to define an uninteresting, monotonous professional work [15]. We believe that such symptoms are characteristic of occupational (emotional) burnout syndrome.

According to the results of T. Koltunovich's (2016) thesis, in Japan the equivalent of burnout is the term "karoshi", which the Japanese call exhaustion, which can lead to suicide or death as a result of the destruction of the adrenal glands, which intensively work in stressful situations and then self-destruction due to the inability to produce hormones [5].

In the Netherlands, the official diagnostic status is called "overstrain" (Neth. - "overspannenheid"), with which since the end of the nineteenth century the so-called mild symptoms of burnout were indicated. The term "burnout" in this country indicates severe symptoms of this disorder (endstate). In Sweden, instead of "burnout", the term "exhaustion syndrome" (utmattningssyndrom) is used, which has an official status and is included into the ICD10 in the Swedish version as a diagnosis [5].

The study and analysis of the scientific psychological and medical literature, the results of a number of studies of the problem of professional burnout leads to the conclusion, that the professional burnout of a teacher of higher medical educational institution - is a condition characterized by the gradual loss of the subject of life tone under the influence of prolonged stress in the professional teaching activity and is manifested by the symptoms of chronic fatigue, general exhaustion, depersonalization, reduction of professional achievements, etc. [5].

The clinical picture of burnout includes a number of non-specific psychopathological, psychosomatic, somatic symptoms and signs of social dysfunction. The most common manifestations are: chronic fatigue, cognitive dysfunction (memory and attention disorders), sleep disorders and personal changes. The development of anxiety-depressive disorder, suicidal and addictive behavior is possible. Common somatic symptoms are: headache, gastrointestinal (diarrhea, irritable bowel syndrome) and cardiovascular (tachycardia, arrhythmia, hypertension) disorders $[1,13]$.

The main reason for professional burnout, in our belief, is that the modern teacher of HMEI today must: be innovative and flexible as for the study and promotion of medical technologies in the student environment, respond to social challenges, be engaged in professional skills improvement and best 


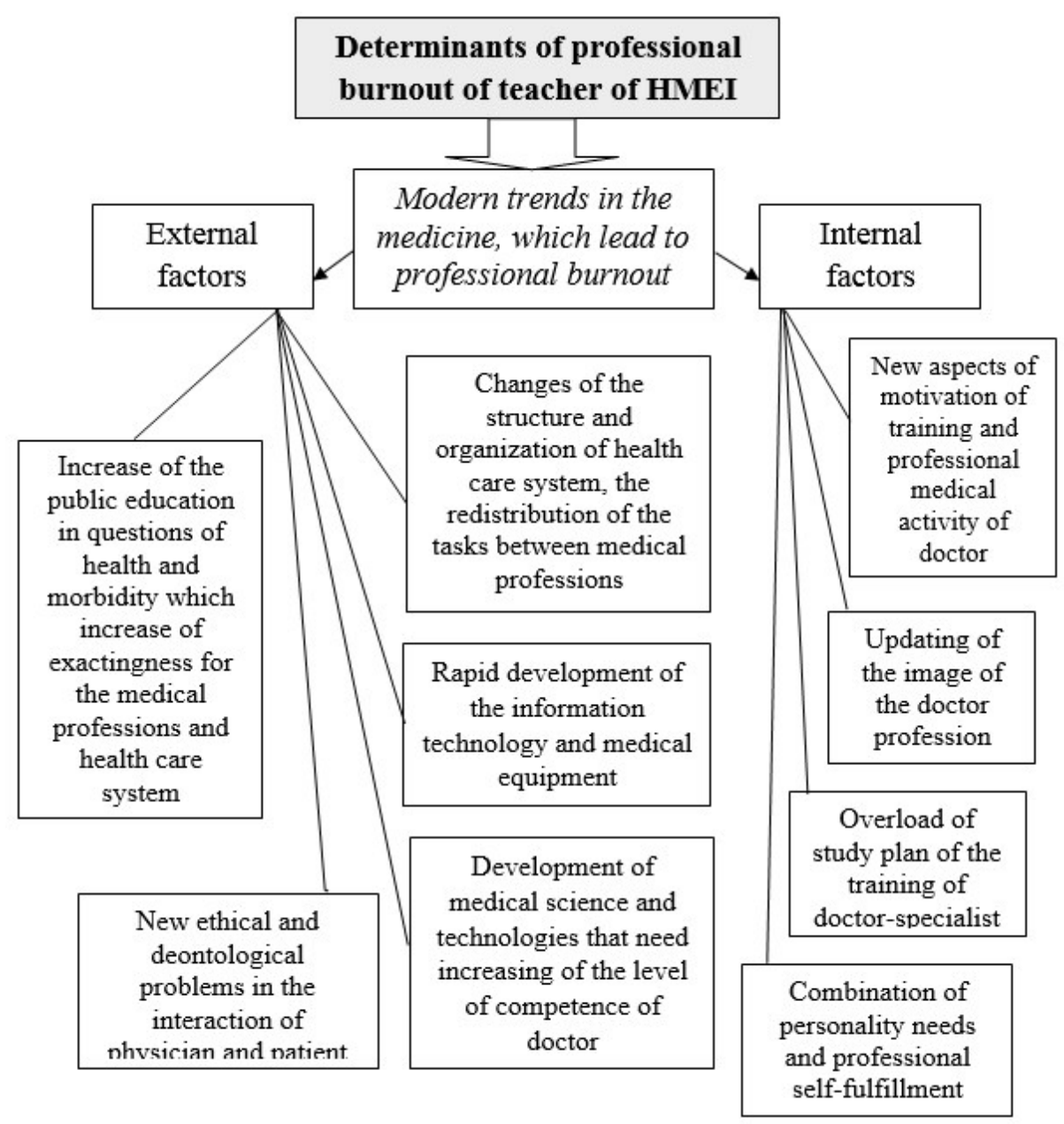

Figure 1. External and internal factors that lead to professional burnout in teachers of HMEI.

foreign experience in this sphere. This is due to external and internal factors [10] (Fig. 1).

Thus, the objective factors of professional (emotional) burnout, are primarily related to the relevant field of activity (in our case, it is a medical university) - chronically intense psycho-emotional activity in the educational process, which involves intensive communication, often increased responsibility for performance the professional functions and educational-scientific tasks; difficulties in adaptation to the environment of foreign students or colleagues; excessively high requirements as for the continuous professional self-improvement, medical training; low level of high school teachers' salary, etc.

Internal (subjective) factors - individual peculiarities of a particular teacher, which actually cause the above-mentioned syndrome - a high level of neuroticism, the existence of inconsistencies in the value sphere, the low level of formation of the individual system of conscious self-regulation and behaviour. At the same time, this division is quite conditional, because in this context it is also necessary to distinguish the dependence of the professional burnout of the teacher on gender characteristics, age and length of scientific-pedagogical work, the existing level of professional competence, emotional instability, dissatisfaction with his/her professional or social status, motives for activities, etc.

It should be noted that the syndrome of professional burnout can lead to a general decrease in the quality of professional activity of the teacher, deformation of interpersonal relationships, as well as a decrease of the activity in creative professional self- 
improvement, self-development. Against this background, there is often a negative attitude towards the participants of the educational process (students, colleagues, administration of the educational institution), towards him/herself and the professionalmedical activity in general, deterioration of mental and physical health (Fig. 2).

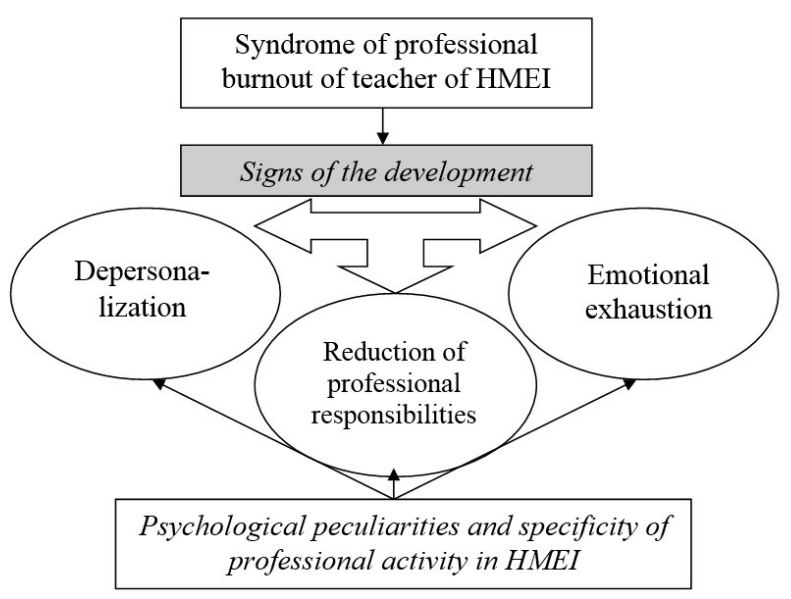

Figure 2. Signs of the development of teacher's professional burnout syndrome.

The model of determinant of the emergence of "professional burnout" syndrome in teachers offered by T.V. Zaychikova includes: 1) socio-economic determinants; 2) socio-psychological determinants; 3) individual-psychological determinants. Study of the correlation between the "professional burnout" syndrome and the personal characteristics of teachers (lecturers) has revealed statistically significant associations between the syndrome and such personal factors as introversion-extraversion, aggression, psychoticism [4].

According to the results of scientific researches (O.I. Petrusenko, S.D. Alekseenko) [6], the dominant component in the structure of emotional burnout of teachers (lectures) is the "resistance" (40.2\% of respondents), which is characterized by the shutting down the professional skills, the reduction of the level of interpersonal interaction with colleagues and students, the expansion of the sphere of "economy" of emotions, inadequate emotional response. At the same time, only $17.5 \%$ of respondents found a high level of development of the "stress" compo- nent, and in $12.5 \%$ of respondents - a high level of development of the third component of the syndrome - "exhaustion".

\section{Conclusions}

The problem of professional burnout is interdisciplinary in nature and is mostly characteristic of the "person-to-person" professions. Occupational burnout syndrome - is the result of a mental disorder of the subject of professional activity, its emotional, mental and physical exhaustion, which significantly affects the quality of teaching in IHME, lowers the motivation of work, causes indifference to the improvement of professional competence and creative self-development in this sphere.

"Professional burnout", as Z.O. Rzhevska-Shtefan notices - is a destructive phenomenon of the professional formation of the personality of a high school teacher [in our case - HMEI]. The most pronounced component of the "burnout" symptom complex is the "resistance" - excessive emotional exhaustion, which causes the emergence and development of protective reactions that make the teacher emotionally closed, distant and indifferent to professional activity. According to the scientist, the specificity of the development of "burnout" in teachers is that against the backdrop of symptoms of "resistance" they have clearly manifested "exhaustion", which testify the beginning of destructive personality changes and the presence of negative emotional attitudes toward students, colleagues and professional activity as a whole, the so-called psychological protection which he/she uses, are no longer able to help him to deal with stress and overload. At the same time, the professional burnout of the teacher adversely affects not only his/her condition, but also to a lesser extent - the professional formation of the medical student [7]. In this sense, there are the threats and risks of ensuring the quality of professional training of future health care professionals.

In order to prevent professional burnout in teachers of the HMEI, we consider it timely to diagnose this symptom. The level of professional burnout of the teacher is determined by the following individual indices: perfectionism, emotional stability, 
spontaneous aggression, self-esteem, personal anxiety, neuroticism, empathy, indifference, existential content, self-blame, over-responsibility, etc.

Factors such as: psychological self-regulation; harmonization of self-esteem and self-assessment of his/her professional abilities and achievements; development of professional reflection and skills of professional communication; increase of stress resistance, etc., serve to prevent the professional burnout.

\section{Prospects of Further Researches}

The prospects for further scientific research is in determination of the dominant factors and the most effective strategies for prevention and overcoming the professional burnout syndrome in teachers of higher medical educational institutions.

\section{References}

[1] Abramova GS, Yudchits YUA. Sindrom «emotsionalnogo vigoraniya» $\mathrm{u}$ medrabotnikov. Psikhologiya v meditsine. M: Kafedra-M; 1998. 231-44.

[2] Ananyev BG. O problemakh sovremennogo chelovekoznaniya. M: Nauka; 1977. 380 s.

[3] Bilynska M. Standarty vyshchoyi medychnoyi osvity yak shlyakh do mizhnarodnoyi akredytatsiyi medychnoyi shkoly. Visnyk UADU. 2002; 4:150-55.

[4] Zaychykova TV. Sotsialno-psykholohichni determinanty syndromu «profesiynoho vyhorannya $\gg$ u vchyteliv [avtoreferat]. Kyiv: 2005. 20 s.

[5] Koltunovych TA. Psykholohichni umovy korektsiyi profesiynoho vyhorannya u vykhovateliv dytyachykh navchalnykh zakladiv [dysertaciia]. Ivano-Frankivsk: Prykarpatskyy natsionalnyy universytet imeni Vasylya Stefanyka; 2016. $352 \mathrm{~s}$.

[6] Petrusenko OI, Alyeksyeyenko SD. Determinanty syndromu «profesiynoho vyhorannya» $\mathrm{u}$ pedahohichnykh pratsivnykiv $\mathrm{v}$ aspekti psykholohichnoho zdorovya. Visnyk Dnipropetrovskoho universytetu. Seriya $\ll$ Pedahohika i psykholohiya». 2013;19:117-23. http://psyresearch.dp.ua/index. php/psy/article/download/72/74

[7] Rzhevska-Shtefan ZO. Osoblyvosti «profesiynoho vyhorannya» vykladachiv vyshchykh navchalnykh zakladiv. Problemy suchasnoyi psykholohiyi. Zbirnyk naukovykh prats K-PNU imeni Ivana Ohiyenka, Instytutu psykholohiyi imeni H.S.Kostyuka NAPN Ukrayiny. 2013;19:614-24.

[8] Systema profesiynoyi pidhotovky fakhivtsiv dlya haluzi okhorony zdorovya Ukrayiny. https://www.sq.com. ua/rus/news/teksty/20.05. $2009 /$ sistema_profesijnoyi_ pidgotovki_fahivciv_dlya_ galuzi_ohoroni_zdorovya_ ukrayini/

[9] Khardi I. Vrach, sestra, bolnoy. Psikhologiya raboty s bolnymi. Budapesht: Izd-vo AN Vengrii; $1988.338 \mathrm{~s}$.

[10] Dubasenyuk OA, Kalininoyi LV, Antonovoyi OYE, editors. Suchasni tendentsiyi profesiynoyi pidhotovky medychnykh pratsivnykiv v Ukrayini. Aktualni problemy profesiynopedahohichnoyi osvity ta stratehiyi rozvytku. Zhytomyr: Vyd-vo ZHDU; 2006:70-3.

[11] Budnyk O. Educational model of a modern student: european scope. J of Vasyl Stefanyk Precarpathian National University. Scientific Edition: Series of Social and Human Sciences. 2016; 3(2-3):9-14. DOI: https://doi. org/10.15330/jpnu.3.2-3.9-14

[12] Freudenberger HJ. The issues of staff burnout in therapeutic communities. J Psychoactive Drugs. 1986 Jul-Sep; 18(3):24751. DOI: https://doi.org/10. $1080 / 02791072.1986 .10472354$ [PMid:3772650] 
[13] Kelley K, Byrne D, Przybyla DPJ, Eberly C, Eberly B, Greendlinger V, et al. Chronic self-destructiveness: Conceptualization, measurement, and initial validation of the construct. Motiv Emot. 1985 Jun; 9(2):13551. DOI: https://doi.org/10.1007/ BE 00991572

[14] Schaufeli W, Maslach C, Marek T, editors. Professional burnout: Recent developments in theory and research. Washington DC: Taylor \& Francis; 1993. 292 p.

[15] Rothlin Ph, Werder PR. Diagnose Boreout: warum Unterforderung im Job krank macht. Heidelberg: Redline Wirtschaft; 2007. 136 p.

Received: $2019-12-09$

Revised: 2019-12-18

Accepted: $2019-12-18$ 